\title{
Germ cell differentiation-dependent and stage-specific expression of LANCL1 in rodent testis
}

\author{
J.E. Nielsen, ${ }^{*}$ M.A. Hansen, ${ }^{*}$ M. Jørgensen, ${ }^{*}$ M. Tanaka, ${ }^{\circ \# ~ K . ~ A l m s t r u p, ~}{ }^{*}$ N.E. Skakkebæk, ${ }^{* \#}$ \\ H. Leffers*\# \\ *Dept. of Growth and Reproduction, Rigshospitalet, Copenhagen, Denmark; 'Dept. of Pharmacology,

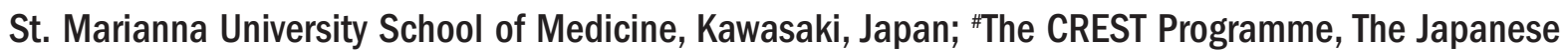 \\ Science and Technology Corporation, Japan
}

(C)2003, European Journal of Histochemistry

LANCL1 (LanC-like protein 1) is related to the bacterial LanC (lanthionine synthetase C) family, which is involved in the biosynthesis of antimicrobial peptides. Highest expression levels of LANCL1 are found in testes and brain, two organs that exist behind blood-tissue barriers. In the mouse, the establishment of an impermeable blood-testis barrier occurs between day 10-16 post natal (pn). Differential display analysis showed that the expression level of LANCL1 mRNA in mouse testes was very low until day 16 pn, but increased gradually from day $16 \mathrm{pn}$ to reach a maximum on days 2224 pn followed by a slight reduction from day 26 pn to adult animals. Thus, the expression of LANCL1 mRNA is initiated following the establishment of the blood-testis barrier. In situ hybridisation revealed that LANCL1 mRNA was induced in diplotene spermatocytes, which appear for the first time in mouse testes between days 18 and 20 pn, verifying the expression profile determined by differential display. LANCL1 mRNA level remained high in the meiotic division phase and in early round spermatids, but was down regulated in elongating spermatids and it was undetectable in step 9 elongating spermatids in stage IX (as defined by Russel et al., 1990). The steady decrease in expression level from round spermatids in stage I to elongating spermatids in stage IX suggested that LANCL1 mRNA was not transcribed in spermatids. LANCL1 expression in rat testes was initiated already in pachytene spermatocytes in stage IX, but otherwise similar to mouse.

Key words: blood-testis barrier, LANCL1, spermatogenesis, in situ hybridization.

Correspondence: Dr. Henrik Leffers, University Dept. of Growth and Reproduction, Section GR-5064, Rigshospitalet, Blegdamsvej 9, DK-2100 Copenhagen, Denmark. Phone: international +45.35457934. Fax: international +45 . 35456054. E-mail: henrik.leffers@biobase.dk

Paper accepted on May 7, 2003

European Journal of Histochemistry

2003; vol. 47 issue 3 [Jul-Sept]: 215-222
LANCLI (LanC-like protein 1) is a peripheral membrane protein, which is related to the LanC (lanthionine synthetase $\mathrm{C}$ ) family of bacterial membrane-associated proteins. LanC proteins are involved in the biosynthesis and transport of uniquely modified lanthionine-containing antimicrobial peptides, the so-called lantibiotics (lanthionine-containing antibiotic) (Bauer et al., 2000; McAuliffe et al., 2001). While lantibiotics are produced by Gram-positive bacteria, functionally similar defence peptides exists in higher organisms, including plants, insects and mammals, and play an important role in the innate immune system (Borregaard et al., 2000). Thus, LANCLI may have a function similar to bacterial LanC proteins as a peptide-modifying enzyme (Bauer et al., 2000).

Mayer and colleagues (Mayer et al., 2001) demonstrated that the expression of LANCLI is tissue-specific, the highest expression levels of rat LANCLI are found in testes and brain. These organs exist behind blood-tissue barriers designed to minimise the passage of cells and macromolecules into the parenchyma. Immunological surveillance of both organs does occur, and by mechanisms similar to those for other organs, but cells and immunoglobulins of the immune system pass through in markedly lower numbers (Hickey, 2001). High expression of $L A N C L I$ may provide an alternative mechanism for immune surveillance of testes and brain. Inspection of the mouse EST sequences corresponding to $L A N C L I$ revealed that it also is expressed in other tissues, including lung, especially branchial arches, thymus, and mammary gland and in many tumours (UniGene Cluster Mm.20522). The majority of the ESTs are from tissues exposed to the surroundings or exists behind blood-tissue barriers.

In rat testis, radioactive in situ hybridisation (ISH) analyses revealed a strong signal in the germinal cells of the seminiferous tubules (Mayer et al., 2001). At present, however, there are no reports about the germ cell differentiation types that 
express the mRNA or the temporal relationship between LANCLI expression and formation of the blood-testis barrier (BTB). The establishment of BTB, by formation of tight junctions between Sertoli cells, occurs between days 10-16 pn in the mouse and days 15-18 pn in the rat (Vitale et al., 1973; Nagano and Suzuki, 1976; Meyer et al., 1977; Bergmann and Dierichs, 1982; Byers et al., 1991).

In the present study, we have examined the expression of the LANCLI mRNA in mouse testes by competitive PCR differential display (DDRT) during post natal development and by a novel ISH protocol in adult testes. The former showed the temporal expression and the latter showed spatial expression allowing precise assignment of the mRNA to distinct germ cell types in rodent testes, which appear on distinct days during development (Bellvé et al., 1977). Monitoring the expression of LANCLI MRNA, we observed a distinct up-regulation from days 16-18 pn reaching its maximum on days 22-24 pn, correlating with the establishment of BTB. In agreement with this, LANCLI mRNA was induced in primary spermatocytes in the diplotene phase (stage XI), which appear in the testis around days 18-20 pn. The expression in rat testes was similar, but initiated in pachytene spermatocytes in stage IX. In both mouse and rat, expression of LANCLI mRNA remained high during the meiotic divisions and in early round spermatids.

\section{Materials and Methods}

\section{Animals}

$\mathrm{C} 3 \mathrm{H} / \mathrm{He}$ mice strain and CDI rats (Japan SLC, Shizuoka, Japan) were maintained under controlled conditions $\left(22 \pm 2^{\circ} \mathrm{C}, 55 \pm 5 \%\right.$ humidity, $12 \mathrm{hr}$ light/dark cycle) and were given laboratory chow (CE-2, Nippon CREA, Tokyo, Japan) ad libitum. Female mice were housed with males, and for both mice and rats the morning when the vaginal plug was found was designated day 1 of gestation. Pregnant females (mice and rats) were housed individually and gave birth to pups on gestational day 20 (mice) or day 23 (rats) and the day of birth was termed day 1 pn. Testes were removed and used either for preparation of total RNA or fixed in $4 \%$ paraformaldehyde in $0.1 \mathrm{M}$ phosphate buffer, $\mathrm{pH}$ 7.4 , overnight at $4^{\circ} \mathrm{C}$, and dehydrated in ethanol. Alternatively, fixation in Stieves fixative (Solution
I: $90 \mathrm{~g} \mathrm{HgCl}_{2}$ in $1.5 \mathrm{I} \mathrm{H20}$; Solution II: $400 \mathrm{~g}$ formaldehyde and $80 \mathrm{~g}$ glacial acetic acid in $1 \mathrm{I}$ $\mathrm{H} 20$; just before use mix $38 \mathrm{~mL}$ Solution I and 12 $\mathrm{mL}$ Solution II) at $4^{\circ} \mathrm{C}$ for $24 \mathrm{hr}$ to $96 \mathrm{hr}$. Mouse testes were prepared from day 1 pn, and every day until day 4 pn, and then on every second day until day 52 pn.

\section{Differential display analysis}

Total RNA was prepared using the RNeasy kit as described by the manufacturer (Qiagen, Hilden, Germany) and cDNA was prepared as described previously (Jørgensen et al., 1999) using one-baseanchored AAGCTIIV ( V = A, C or G) downstream primers. All solutions were treated with diethylpyrocarbonate (DEPC) or made from DEPC-treated water. DDRT was subsequently performed using either one- or two-base-anchored primers (AAGCTIIVN; $N=A, C, G$ or $T$ ) in combination with a range of upstream primers. The $L A N C L I$ mRNA band was displayed by the upstream primer CATAGAAATGGCGGACA in combination with either AAGCTIICA or AAGCTI1CC. Bands were excised from the DDRT gels and re-amplified using the same upstream primer and a downstream primer that was extended at the 5'-end with a T7 promoter sequence (taatacgactcactataggg-AAGCT $11 \mathrm{~V}$; T7 promoter sequence in small letters), allowing direct sequencing with a Cy5-labelled T7-promoter complementary primer. The expression level on different days was quantified by phosphor imaging (semiquantitative analysis). All methods relating to DDRT have been described in details previously (Jørgensen et al., 1999; Jørgensen et al., 2000). Synthesis of cDNA using one-baseanchored primers allow subsequent DDRT analysis using two-base-anchored primers (unpublished results; Figure 1). A FASTA search against public databases showed that the displayed DNA fragment had a 100\% match to 220 nucleotides in the terminal 3'-end of the LANCLI mRNA (acc. no. AJ294535).

\section{Preparation of biotin labelled probe for ISH}

The mouse LANCLI mRNA probe was derived from the DDRT DNA fragment and prepared by reamplification of the fragment using a nested primer specific to the LANCLI mRNA with an added T3promoter sequence (aattaaccctcactaaaGGGATGG CTGGAACAAT; T3-promoter sequence in small letters) in combination with the T7-extended down- 
stream primer. $\mathrm{PCR}$ conditions were: $5 \mathrm{~min} 95^{\circ} \mathrm{C} ; 5$ cycles of: $30 \mathrm{sec} 95^{\circ} \mathrm{C}, 1 \min 45^{\circ} \mathrm{C}, 1 \min 72^{\circ} \mathrm{C} ; 20$ cycles of $30 \mathrm{sec} 95^{\circ} \mathrm{C}, 1 \mathrm{~min} 65^{\circ} \mathrm{C}, 1 \mathrm{~min} 72^{\circ} \mathrm{C}$ and finally $5 \mathrm{~min} 72^{\circ} \mathrm{C}$. The resulting PCR product was purified on a $2 \%$ low melting point agarose gel and sequenced from both ends, using Cy5-labelled primers complementary to the added T3 and T7 tags. Aliquots of about $200 \mathrm{ng}$ were used for in vitro transcription labelling, using the MEGAscript-T3 (sense) or MEGAscript-T7 (anti-sense) kits as described by the manufacturer (Ambion, Houston, TX, USA). The composition of the $10 \times$ nucleotide mix was: $7.5 \mathrm{mM}$ ATP, GTP and CTP, $3.75 \mathrm{mM}$ UTP, $1.5 \mathrm{mM}$ biotinlabelled UTP. To estimate quantity and labelling efficiencies, aliquots of the labelled RNA product were analysed by agarose gel electrophoresis, and spotted onto nitrocellulose filters and developed as described below.

\section{In situ hybridization}

Tissue sections ( 8 to $10 \mu \mathrm{m}$ ) were placed on silane-coated slides (van Prooijen-Knegt et al., 1982) and heated to $60^{\circ} \mathrm{C}$ for $1 \mathrm{hr}$ followed by over night incubation at $42^{\circ} \mathrm{C}$. All solutions were treated with DEPC or made from DEPC-treated water. Paraffin was removed by two treatments with xylen and one with $99 \%$ ethanol followed by $95 \%, 70 \%$ ethanol, all for $5 \mathrm{~min}$. The sections were then refixed with $4 \%$ paraformaldehyde (PFA) in $1 \times$ PBS (10 x PBS: $1.37 \mathrm{M} \mathrm{NaCl}, 40 \mathrm{mM} \mathrm{KCl}, 125$ $\mathrm{mM} \mathrm{NaH} \mathrm{PO}_{4}, 11.5 \mathrm{mM} \mathrm{Na}_{2} \mathrm{HPO}_{4}, \mathrm{pH}$ 7.4) for 5 min followed by 2 min in water. The slides were treated with Proteinase K (P-2308, Sigma, St Louis MO USA) in the range of $1.0-12.5 \mu \mathrm{g} / \mathrm{mL}$ in TES buffer $(0.01 \mathrm{M}$ Tris- $\mathrm{HCl}, 0.1 \mathrm{M} \mathrm{NaCl}, 5 \mathrm{mM}$ EDTA, $1 \%$ o Triton X-100) for $15-30$ min at $37^{\circ} \mathrm{C}$. The slides were subsequently washed in $1 \times$ PBS for $2 \times 2$ min, re-fixed with $4 \%$ PFA in $1 \times$ PBS for 5 min and washed for $2 \times 15$ min in $1 \times$ PBS followed by $15 \mathrm{~min}$ in $5 \times$ SSC. The slides were pre-hybridised for $1 \mathrm{hr}$ at $50^{\circ} \mathrm{C}$ in $5 \mathrm{~mL}$ deionised formamide, $2.5 \mathrm{~mL} 20 \times \mathrm{SSC}, 0.25 \mathrm{~mL}$ Denhardts solution (D2532, Sigma), $0.25 \mathrm{~mL} 1 \mathrm{M}$ sodium sulphate buffer $\mathrm{pH} 7.0$, and $2 \mathrm{~mL}$ water supplemented with $8 \mu \mathrm{L}$ yeast tRNA (Cat. no. 15401-011, Gibco BRL, Rockville, MD, USA) and $10 \mu \mathrm{L} 0.5 \mathrm{M}$ EDTA. The hybridisation solution was similar to the prehybridisation, except that the DEPC-treated water was replaced with 50\% Dextran sulphate (D-8906, Sigma) in DEPC-treated water. Probes were heated to $80^{\circ} \mathrm{C}$ before application, and the slides were placed in an atmosphere saturated with $50 \%$ formamide/water at $50^{\circ} \mathrm{C}$ for $20 \mathrm{hr}$. After hybridisation, cover slides were removed in $2 \times$ SSC and after 15 min at room temperature in $2 \times$ SSC washing continued in $0.1 \times$ SSC supplemented with 50 mM EDTA for $3 \times 30 \mathrm{~min}$ at $58{ }^{\circ} \mathrm{C}$, followed by incubation for $5 \mathrm{~min}$ in $1 \times$ TBS $(10 \times$ TBS: $1 \mathrm{M}$ Tris- $\mathrm{HCl}$ and $1.5 \mathrm{M} \mathrm{NaCl}, \mathrm{pH} 7.5$ ). Slides were subsequently incubated with streptavidin conjugated with alkaline phosphatase (1:1000) (Cat. No. 1093266, Roche Diagnostics GmbH, Mannheim, Germany) and excess streptavidin was removed by washing in $1 \times$ TBS for $2 \times 5$ min followed by $5 \mathrm{~min}$ in development buffer $(0.1 \mathrm{M}$ Tris $\mathrm{HCl} \mathrm{pH}$ 9.5; 0.1 $\mathrm{M} \mathrm{NaCl} ; 50 \mathrm{mM} \mathrm{MgCl}_{2}$ ). Development was performed in development buffer ( $10 \mathrm{~mL}$ supplemented with $45 \mu \mathrm{L}$ BCIP $(50 \mathrm{mg} / \mathrm{mL}$ in dimethylformamide; Sigma, B-8503), $35 \mu \mathrm{L}$ NBT $(75 \mathrm{mg} / \mathrm{mL}$ in dimethylformamide; Sigma, N-6876) and 12.5 $\mu \mathrm{L} 1 \mathrm{M}$ Levamisol (L-9756, Sigma). Finally, the sections were mounted in GVA (00-8000, Zymed, San Francisco, CA, USA).

\section{Results}

In a DDRT screening for mRNAs that were upregulated during spermatogenesis, we identified a band that showed a distinct expression profile (Figure 1). Sequencing showed that the band corresponded to the LANCLI mRNA. The band was displayed by the upstream primer CATAGAAATGGCGGACA combined with the HTIICA downstream primer. Sequencing of a band that showed a similar expression profile and was displayed by the same upstream primer, but in combination with a HTIICC downstream primer revealed that it also corresponded to LANCLI mRNA (Figure 1). Inspection of LANCLI mRNA and EST sequences (Bauer et al., 2000; UniGene Cluster Mm.20522) showed that the 3'-sequences immediately preceding the poly-A tract was: TGGT-Poly-A, TGG-PolyA or TG-Poly-A, with the latter being the most common. Thus, LANCLI mRNAs are slightly heterogeneous in the $3^{\prime}$-end and this was reflected in the band being displayed by two different two-baseanchored downstream primers.

\section{Expression of LANCL1 during development}

Expression of the LANCLI mRNA was examined in mouse testes from day 1 pn until day 52 pn. During in utero development, LANCLI mRNA was expressed 


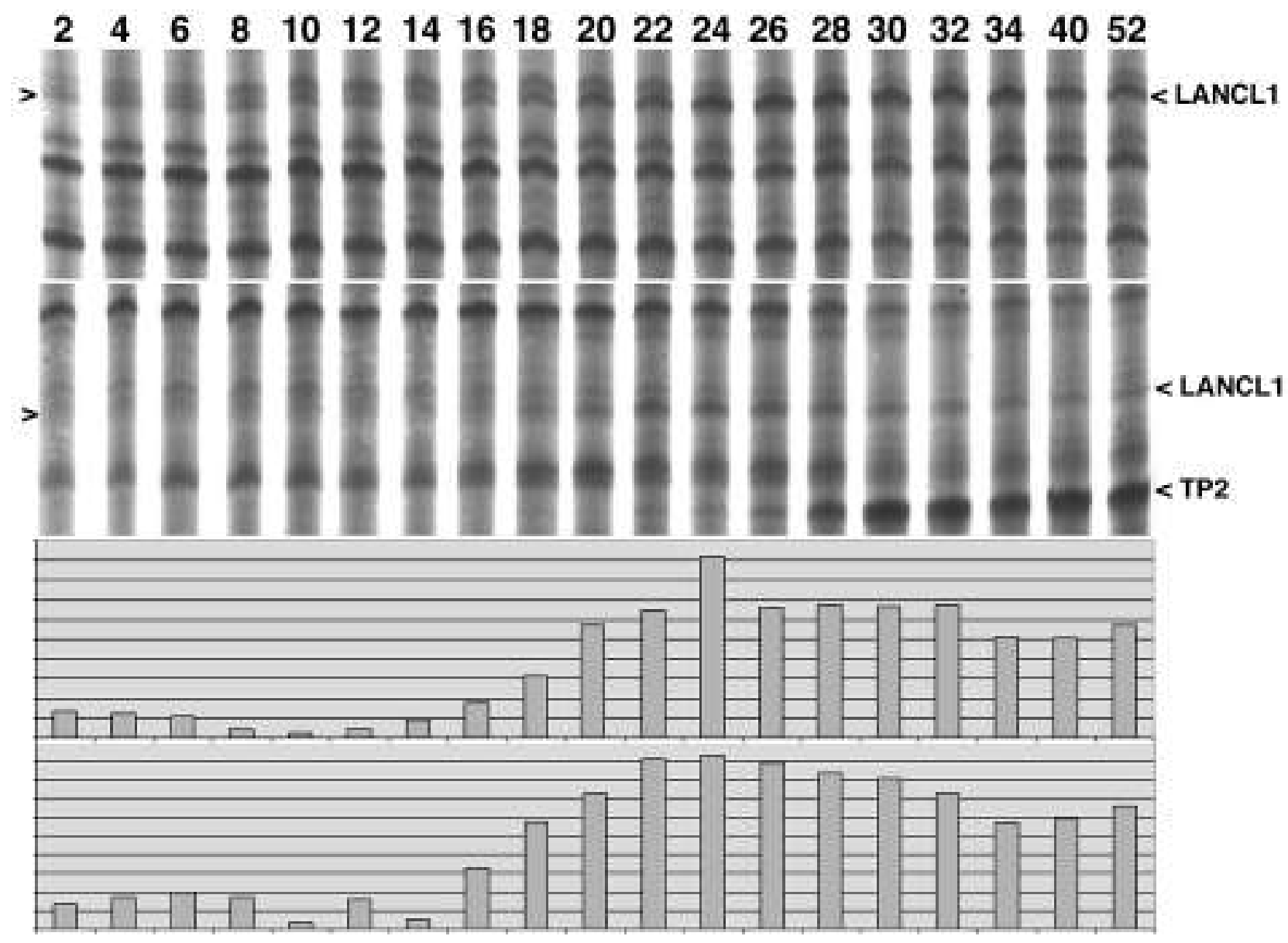

Figure 1. Expression of LANCL1 mRNA in mouse testes during post-natal development. A band corresponding to LANCL1 mRNA was displayed by two different primer combinations, using different two-base-anchored downstream primers and the same upstream primer. $A$ and $B$, upstream primer CATAGAAATGGCGGACA in combination with downstream primers HT11CA and HT11CC, respectively. C and $D$, phosphorimager quantification of the LANCL1 mRNA bands in A and B, respectively. Sequencing of some of the other displayed bands revealed that one corresponded to transition protein 2 (TP2; indicated on B). The TP2 mRNA is restricted to post meiotic spermatids (Shih and Kleene, 1992), which also is suggested by its up-regulation on day 28 pn. Note the different band pattern resulting from the use of downstream primers differing only by the 3 '-nucleotide.

at a very low level (not shown) and the expression level remained low after birth until day 16 pn from where it increased gradually to reach a maximum on days 22-24 pn (Figure 1). This was followed by a slight decrease from day 26 pn, but the level remained high in adult animals (Figure 1 ). The expression profile suggested that the mRNA was upregulated in differentiated germ cells that appeared around days 16-18 pn, and that its expression was restricted to a relatively short period during germ cell differentiation. The reduction in expression level from day 26 pn was most likely caused by the appearance of more differentiated germ cells that contributed to the pool of total RNA, but did not express LANCLI mRNA (Ivell and Spiess, 2002).

\section{ISH analysis of LANCL1 mRNA expression in mouse testis}

The observed up-regulation suggested that LANCLI was upregulated in cells appearing on days 16-18, which should correspond to late pachytene spermatocytes or diplotene spermatocytes (Bellvé et al., 1977; Goetz et al., 1984). To confirm this, we performed an ISH analysis on adult mice testes using the DDRT fragment as probe. Germ cell differentiation proceeds through a series of steps and germ cells in distinct differentiation steps can be identified because the seminiferous epithelium can be divided into 12 distinct stages, each containing specific germ cell differentiation steps (Russell et al., 1990). Thus, by identifying the stage of the seminiferous epithelium, the 


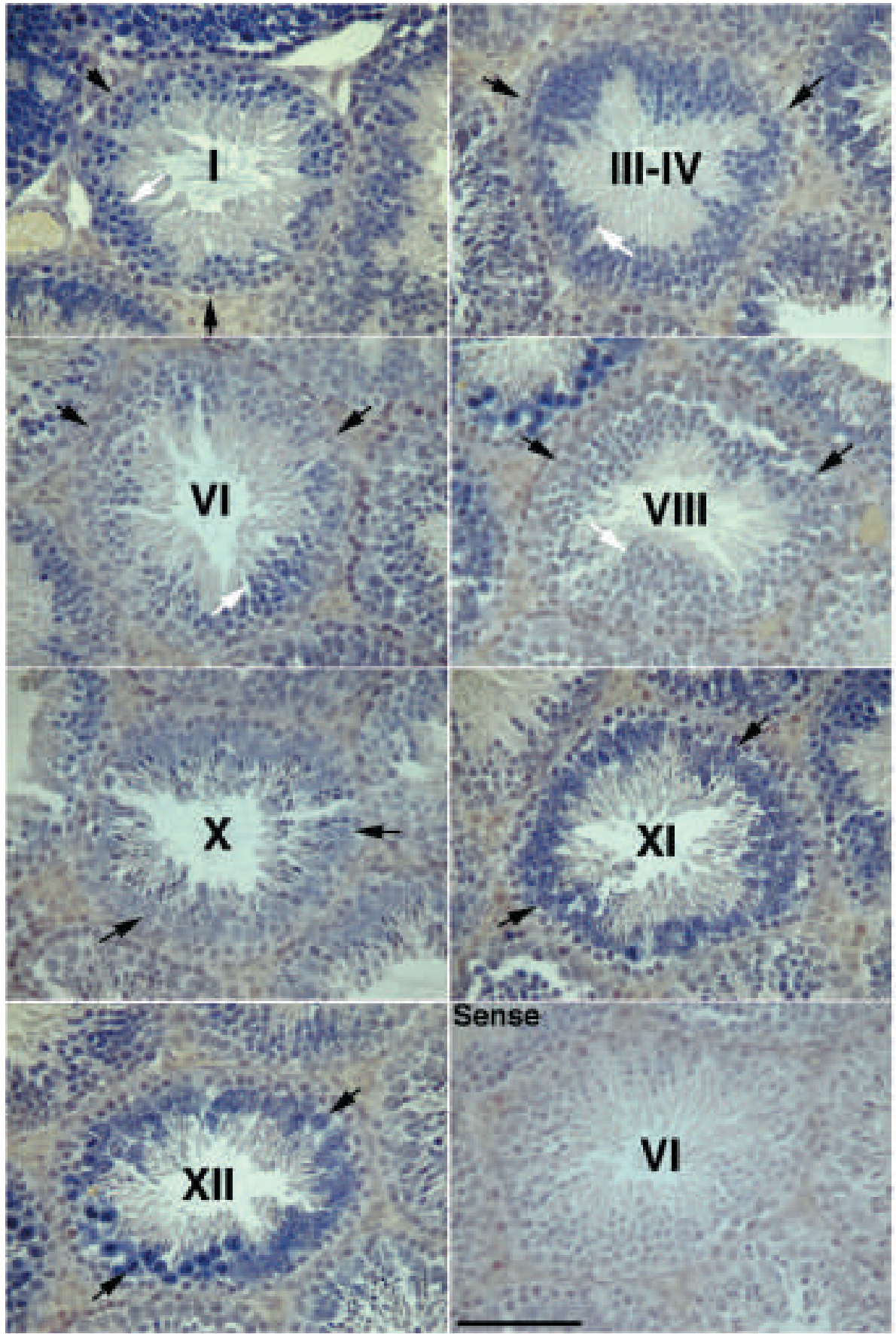

Figure 2. ISH analysis of LANCL1 mRNA expression in mouse testis. Representative stages of the seminiferous epithelium are shown. Examples of germ cells in the pachytene (stages I, III-IV, VIII and X), diplotene (stage XI) and meiotic division (XII) phases are indicated by black arrows; white arrows indicate examples of round spermatids, showing decreasing signal from stage I to VIII. The bar in the sense image corresponds to $100 \mathrm{\mu m}$. LANCL1 MRNA expression increased many fold in pachytene spermatoocytes between stages $X$ and $X I$ and expression continued until the mRNA was undetectable in step 9 round spermatids in stage IX, but expression in spermatids decreased from step 1 in stage $I$. germ cell types can be precisely identified.

In our ISH protocol, sections hybridized with anti-sense and sense probes, respectively, are developed together and the development is continued until a weak staining is observed on the sense-sections. At this time, the anti-sense-sections are normally darker than the sense-sections because the anti-sense probe includes 11 T-residues in the 3'end (derived from PCR-amplification of the DDRT- fragment, see Materials and Methods section). The T-residues will give a weak signal from very weak hybridisation to any stretch of 11 or more Aresidues, i.e. especially mRNAs. The result is a weak yellow to brown staining of all cells, including nuclei, and a much stronger dark-blue to black staining where the specific mRNA, matching the complete probe, is expressed (Figures 2 and 3 ).

Inspection of the ISH sections showed that the 


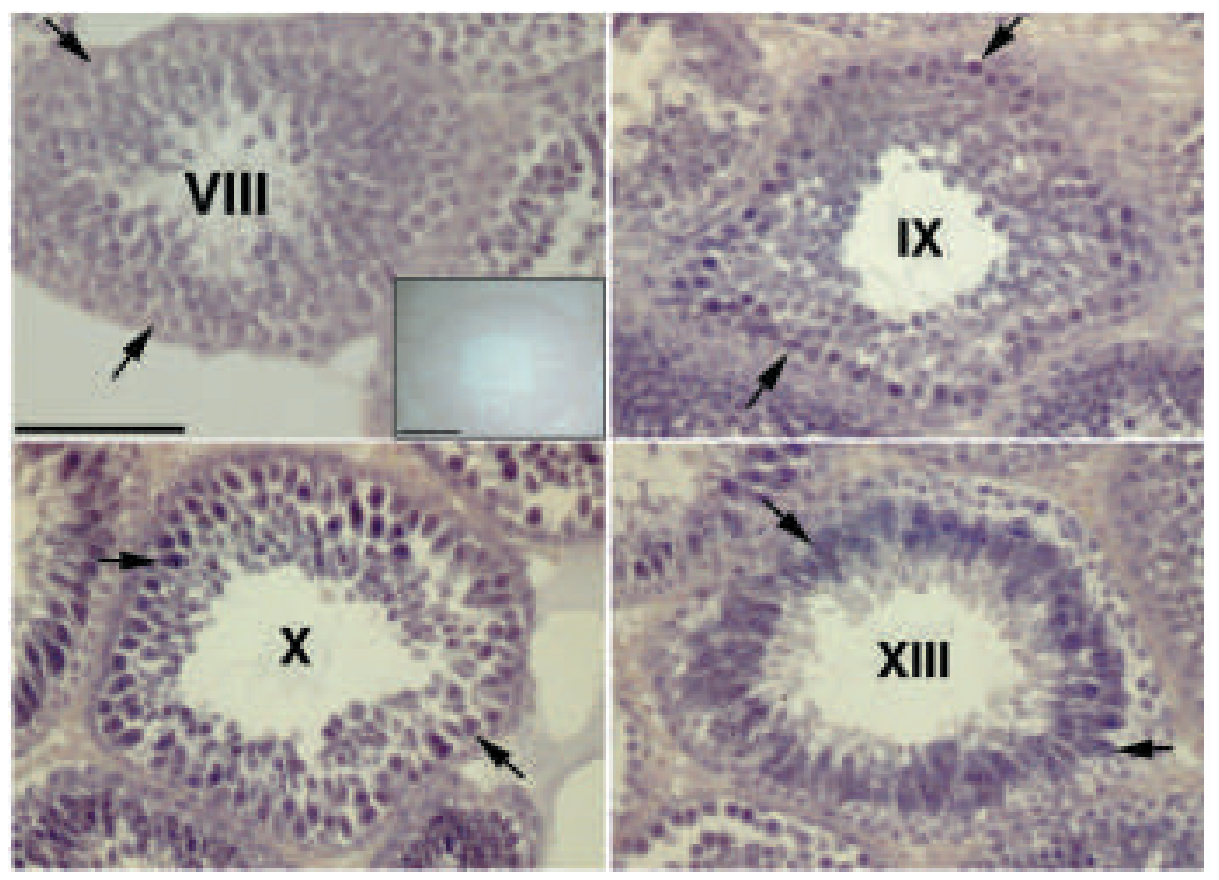

\begin{tabular}{l}
\hline Figure 3. ISH analysis of LANCL1 \\
mRNA expression in rat testis. \\
Arrows indicate germ cells in \\
pachytene and diplotene (stage \\
XIII) stages and black bars indicate \\
$100 \mu \mathrm{m}$. A representative sense \\
control hybridisation is inserted in \\
the stage VIII image. In rat testes, \\
expression was initiated earlier \\
than in mouse since the level of \\
LANCL1 mRNA increased in \\
pachytene spermatocytes between \\
stages VIII and IX. As in mouse, the \\
highest expression was in \\
diplotene spermatocytes in stage \\
XIII: expression continued in round \\
spermatids where it decreased \\
gradually until it was undetectable \\
in elongating spermatids in stage \\
XI.
\end{tabular}

LANCLI mRNA was essentially undetectable in spermatogonia, preleptotene, leptotene, zygotene, and pachytene spermatocytes, but strongly induced in diplotene spermatocytes in stage XI (Figure 2). The expression level remained high in cells in the meiotic divisions phase (diakinesis/metaphase I) in stage XII, and the mRNA was also present in round spermatids, but the level decreased gradually until it was undetectable in step 9 elongating spermatids in stage IX (Figure 2). This suggests that the transcripts in spermatids were derived from transcription in spermatocytes. In conclusion, the temporal expression profile is in accordance with the LANCLI mRNA induced in diplotene spermatocytes, which appear at days 18-20 pn, and it was expressed in a relatively short period during germ cell differentiation.

\section{ISH analysis in rat testis}

The mouse DNA fragments used as probe for ISH was $92 \%$ similar to the corresponding region of the rat $L A N C L I$ mRNA allowing ISH on rat testis using the mouse probe. There are two additional stages of the seminiferous epithelium in rats (14 stages), which are present between mouse stages VIII and IX; thus in the rat, diplotene spermatocytes appear in stage XIII and the meiotic divisions occur in stage XIV (Russell et al., 1990). Other stages are comparable between mouse and rat. ISH analysis of rat testes revealed a cell type specificity that was slightly different from mouse (Figure 3 ).
The LANCLI mRNA was undetectable in pachytene spermatocytes until stage IX where it was upregulated and its expression level increased gradually to reach a maximum in diplotene spermatocytes in stage XIII and in cells in the meiotic divisions in stage XIV (Figure 3). As in mouse, expression continued in spermatids where maximum expression was in round spermatids in stage I followed by a gradual decrease until the mRNA was undetectable in elongating spermatids in stage XI (corresponding to mouse stage IX). Thus, expression of the LANCLI mRNA was essentially similar in rat and mouse, but the mRNA was upregulated earlier and more gradually in rat than in mouse.

\section{Discussion}

A sequence alignment of LANCLI from mouse, human, rat, Drosophila melanogaster and Arabidopsis thaliana against seven LanC and nine LanM sequences from different prokaryotes revealed seven hydrophobic sequence repeats with a GxxG consensus motif (Bauer et al., 2000). These repeats are shared between the eukaryotic homologues and the prokaryotic peptide-modifying enzymes LanC and LanM with a few exceptions in prokaryotes. LanC and LanM are members of a family of peripheral membrane proteins, which are involved in the biosynthesis of antimicrobial peptides constituting an innate defence (Bauer et al., 2000; Mayer et al., 2001). These conserved repeats may suggest con- 
served function of LANCLI and LanC, which is intriguing considering the expression of $L A N C L I$ in germ cells residing in an immune-privileged environment secluded by BTB blocking $T$ lymphocytes and antibodies (Bart et al., 2002).

It is difficult to precisely predict when BTB must be established. In mouse and rat, the BTB develops on days 10-16 pn and 15-18 pn, respectively (Vitale et al., 1973; Nagano and Suzuki, 1976; Bergmann and Dierichs, 1982) which in both animals corresponds to germ cells in the pachytene phase of meiosis (Russell et al., 1990). There is, however, a little discrepancy in the exact timing; Vitale and colleagues (Vitale et al., 1973) reported that BTB in rat testes was not formed on day 15 pn when germ cells had progressed to the pachytene stage whereas Bergmann and Dierichs (1982) reported that $B T B$ was formed on day 15 pn when germ cells progressed from zygotene to pachytene phase. We observed that LANCLI mRNA expression was turned on slowly in rats, starting in pachytene spermatocytes in stage IX corresponding to cells appearing on days 21-23 pn (Russell et al., 1990). Thus the expression of LANCLI mRNA in rats appears to lag behind the formation of the BTB, but may coincide with the establishment of a fully functional BTB.

Expression of LANCLI mRNA in mouse was evaluated using two independent methods, a RTPCR-based analysis during development and an ISH-based identification of the expressing cell types in adult testis. The two technologies resulted in complementary information that essentially verified each other: the expression profile suggested that the mRNA should be present in cell types appearing on days 16-18 pn, which correspond to diplotene spermatocytes (Goetz et al., 1984), and ISH showed that diplotene spermatocytes were the first differentiated germ cell type that expressed LANCLI mRNA. Expression of LANCLI mRNA in rat testes has been reported by Mayer and colleagues (Mayer et al., 2001) who found a high expression of LANCLI mRNA in the germinal cells in the testis illustrated by a radioactive ISH to a single stage of the seminiferous epithelium (stage VII-VIII). However, in our study we actually observe the lowest expression level in germ cells in stage VIII in both rat and mouse (Figures 2 and 3), but our results, nevertheless, confirm their data, as we do detect some expression in round spermatids in stage VIII (Figures 2 and 3). Moreover, in the rat, we observe higher levels of LANCLI mRNA expression in pachytene spermatocytes after stage IX, and in both mouse and rat we find the highest expression in diplotene spermatocytes in stage XI (rat XIII), in cells in the meiotic divisions phase in stage XII (rat XIV), and in early round spermatids in stages I-VI (Figures 2 and 3 ).

The ISH protocol we have used is in several aspects different from other testis ISH manuals. Especially, we have added two additional fixation steps, after de-parifination and after the protease digest. This allows the use a higher concentration of protease to open up the tissue and results in significantly better morphology. However, because of the very different RNA content in different germ cell types and the highly accessible nuclear DNA in pachytene spermatocytes (which also have the highest RNA content), we for some probes observe an artifactual signal from pachytene spermatocytes, typically starting in stage VII-VIII and continuing until just after the meiotic divisions. The intensity of the artifactual signal is in most cases similar in cytoplasm and nucleus. This feature is to a large extent probe-specific and generally only observed for hybridisations where a long development time is required (1-1.5 hr) (i.e. low expressed mRNAs). The problem can be partly resolved by performing a DNase digest to remove the chromosomal DNA, but we have seen examples where we do get a cytoplasmic signal in pachytene spermatocytes in stages VII-XI with probes against mRNAs not present in these cell types. For the LANCLI mRNA probe, we did not detect a signal in pachytene spermatocytes before it was expected from the expression profile. We strongly recommend to use a combination of expression profiling by a sensitive method such as DDRT or real time RT-PCR and ISH to determine the exact expression of an mRNA.

\section{Acknowledgements}

We thank Brian Vendelbo Hansen for excellent technical work. The work was supported by The Japanese Science and Technology Corporation's CREST programme.

\section{References}

Bart J, Groen HJM, van der Graaf WTA, Hollema H, Hendrikse NH, Vaalburg W, Sleijfer DT, de Vries EGE. An oncological view on the blood-testis barrier. The Lancet Oncology 2002;3:357-63.

Bauer $H$, Mayer $H$, Marchler-Bauer A, Salzer U, Prohaska R. Characterization of p40/G PR69A as a peripheral membrane protein related to the lantibiotic synthase component $\mathrm{C}$. Biochem Biophys 
Res Commun 2000;275:69-74.

Bellvé AR, Millette CF, Bhatnagar YM, O'Brian DA. Dissociation of the mouse testis and characterization of isolated spermatogenic cells. J Histochem Cytochem 1977;25:480-94.

Bergmann M, Dierichs R. Postnatal formation of the blood-testis barrier in the rat with special reference to the initiation of meiosis. Anat Embryol 1982;168:269-75.

Borregaard, Elsbach NP, Ganz T, Garred P, Svejgaard A. Innate immunity: from plants to humans. Immunol Today 2000;21:68-70.

Byers S, Graham R, Dai HN, Hoxter B. Development of Sertoli cell junctional specializations and the distribution of the tight-junctionassociated protein ZO-1 in the mouse testis. Am J Anat 1991; 191:35-47.

Goetz P, Chandley AC, Speed RM. Morphological and temporal sequence of meiotic prophase development at puberty in the male mouse. J Cell Sci 1984;65:249-63.

Hickey WF. Basic principles of immunological surveillance of the central nervous system. GLIA 2001;36:118-24.

Ivell R, Spiess AN. Analysing differential gene expression in the testis. Rommerts FFG, Teerds KJ, editors. Testicular Tangrams, $12^{\text {th }}$ European Workshop on molecular and cellular endocrinology of the testis. Springer Verlag; 2002. p. 99-120.

Jørgensen M, Bévort M, Kledal TS, Hansen BV, Dalgaard M, Leffers H. Differential Display Competitive PCR: an optimal tool for assaying gene expression. Electrophoresis 1999;20:230-40.

Jørgensen M, Vendelbo B, Skakkebæk NE, Leffers H. Assaying estrogenicity by quantitating the expression levels of endogenous estro- gen-regulated genes. Environ Health Perspect 2000;108:403-412.

Mayer $\mathrm{H}$, Bauer $\mathrm{H}$, Breuss J, Ziegler S, Prohaska R. Characterization of rat $L A N C L 1$, a novel member of the lanthionine synthase C-like protein family, highly expressed in testis and brain. Gene 2001; 269:73-80.

McAuliffe 0, Ross RP, Hill C. Lantibiotics: structure, biosynthesis and mode of action. FEMS Microbiol Rev 2001;25:285-308.

Meyer R, Polsalky S, McGinely D. Intercellular junction development in maturing rat seminiferous tubules. J Ultrastruct Res 1977; 61:271-83.

Nagano T, Suzuki F. The postnatal development of junctional complexes of the mouse Sertoli cells as revealed by freeze fracture. Anat Rec 1976;185:403-17.

van Prooijen-Knegt AC, Raap AK, van der Burg MJ, Vrolijk J, van der Ploeg M. Spreading and staining of human metaphase chromosomes on aminoalkylsilane-treated glass slides. Histochem J 1982; 14:333-44.

Russell LD, Ettlin RA, Hikim APS, Clegg ED. Histological and histopathological evaluation of the testis. Cache River Press, Clearwater, FL. 1990.

Shih DM, Kleene KC. A study by in situ hybridization of the stage of appearance and disappearance of the transition protein 2 and the mitochondrial capsule seleno-protein mRNAs during spermatogenesis in the mouse. Mol Reprod Dev 1992;33:222-7.

Vitale RD, Fawcett DW, Dym M. The normal development of the bloodtestis barrier and the effects of clomiphene and estrogen treatment. Anat Rec 1973; 176:333-44. 